\title{
Strategi Pemasaran Cabai Merah Pada Sub Terminal Agribisnis Manik Mekar Nadi
}

\author{
NI NYOMAN TISNA DEWI, I NYOMAN GEDE USTRIYANA, \\ A.A.A. WULANDIRA SAWITRI DJELANTIK \\ Program Studi Agribisnis, Program Non Reguler, Fakultas Pertanian, \\ Universitas Udayana \\ J1. PB Sudirman 80232 Denpasar \\ Email: tisnadewi05@gmail.com \\ komingbudi@yahoo.com
}

\section{Abstract \\ The Marketing Strategies of Red Chili at Sub Terminal Agribusiness Manik Mekar Nadi}

Red chili is one type of commercial vegetable that has long been cultivated in Indonesia. STA Manik Mekar Nadi has implemented marketing strategies to market its agricultural production, especially red chili. The purpose of the study was to analyze the internal and external factors, as well as the right strategies to be carried out by STA Manik Mekar Nadi in the marketing of red chili. The choice of location was done purposively and the number of the key informants was seven peoples. Results of research of marketing strategies of red chili showed that the internal factors include: the strength factors, namely, its strategic location, complete facilities, regular customers, and the guaranteed quality of red chili, while the weakness factors, namely, lack of capital, perishable products, unable to meet the demand, not using the services / advertising in the mass media. External factors include: opportunity factors, namely increasing purchasing power of consumers, government supports, increased domestic market demand, and technological development support, while the threat factors, namely, the emergence of new similar competition, consumers 'sensitivity to price changes, fluctuations in the price of red chili at the local farmers, and the stronger bargaining power of consumers. The strategies adopted by STA Manik Mekar Nadi in marketing the red chili are to maintain the quality of red chili, to expand markets and product distribution, to increase the production of red chili, to have capital loans, promotion of technology, product standardization, standardization of prices, to expand business networks, to increase operational facilities, to maintain the stability of prices at the consumer level, and to increase the stock of red chili. The STA Manik Mekar Nadi is recommended to apply for financial assistance to the government, to add transportation and to enlarge the warehouse, as well as to conduct promotion.

Keywords: marketing strategies, red chili, internal factor, external factor 


\section{Pendahuluan}

\subsection{Latar Belakang}

Pertanian merupakan salah satu sektor yang memegang peranan penting dalam bidang perekonomian di Indonesia. Sektor pertanian merupakan sumber penghasilan bagi sebagian besar penduduk Indonesia. Keadaan geografis Negara Indonesia yang merupakan wilayah tropis, beriklim basah, serta berada di wilayah khatulistiwa yang sangat cocok dan mendukung untuk digunakan dalam budidaya tanaman pertanian khususnya subsektor hortikultura mencakup tanaman sayuran, buah-buahan, tanaman hias, dan tanaman obat-obatan. Sayur-mayur banyak mengandung vitamin, mineral, dan serat yang sangat diperlukan oleh tubuh. Kesadaran konsumen atau masyarakat luas tentang pentingnya kualitas bahan makanan semakin meningkat seiring dengan meningkatnya pendidikan, daya beli, dan kesadaran gizi. Adanya pergeseran pradigma terhadap kesehatan, yaitu mengurangi bahan-bahan kimia atau pestisida dalam bahan makanan yang menimbulkan residu atau kontaminasi khususnya pada sayur-mayur, sehingga konsumen menginginkan adanya sayur mayur yang bermutu baik (aman untuk dikonsumsi), segar dan tersedia secara kontinyu. Menurut Satyanaraya (2006), cabai merah (capsicum annum L) merupakan salah satu jenis sayuran komersial yang sejak lama telah dibudidayakan di Indonesia. Cabai merah banyak digunakan sebagai bahan baku industri pangan, meskipun cabai merah bukan bahan pangan utama masyarakat Indonesia, namun komoditi ini tidak dapat ditinggalkan. Berdasarkan catatan Ditjen Hortikultura, Departemen Pertanian (2004), cabai merah mengandung banyak zat gizi yang sangat diperlukan untuk kesehatan tubuh manusia, cabai merah mengandung protein, lemak, karbohidrat, kalsium, fosfor, besi, vitamin-vitamin, dan mengandung senyawa-senyawa alkaloid, seperti capsaicin, flavenoid, dan minyak esensial.

Berdasarkan BPS (2014), produksi cabai merah di Bali tahun 2014 sebesar 20.349 ton dengan luas panen 1.452 ha, mengalami peningkatan sebesar 4.918 ton (31,87 persen) dengan luas panen 1.126 ha di bandingkan tahun 2013, sedangkan pada tahun 2012 produksi cabai merah hanya 13.784 ton dengan luas panen 1.146 ha. Produksi cabai merah tahun 2014 terbesar dihasilkan di Kabupaten Bangli sebesar 8.968 ton, Kabupaten Karangasem menghasilkan 5.868 ton cabai merah, sedangkan kabupaten-kabupaten lainnya secara total memproduksi sebesar 5.513 ton cabai merah. Melihat hasil produksi cabai merah di Provinsi Bali dari tahun ke tahun yang terus mengalami peningkatan, menuntut adanya suatu sistem pemasaran yang lebih adil dan efisien untuk hasil-hasil pertanian dalam hal ini cabai merah, antara lain dengan mengembangkan kelembagaan pemasaran yang secara ideal dibangun dari, oleh, dan untuk para petani produsen yang bersangkutan. Bentuk kelembagaan itu ialah berupa Sub Terminal Agribisnis (STA) yang dibangun pada pusat-pusat (sentra) produksi tanaman pertanian. STA bertujuan untuk memutus rantai pemasaran yang panjang, selain itu sebagai sarana untuk mengakomodasi berbagai kepentingan pelaku agribisnis, misalnya sarana dan prasarana pengemasan, sortasi, penyimpanan, transportasi serta pelatihan (Sinartani, 2014). 
Menurut Majalah Bali Mandara (2016), ketua STA Manik Mekar Nadi I Gusti Ngurah Alit, pada tahun 2009 mendapat penghargaan dari Menteri Petanian Republik Indonesia sebagai petani teladan dan pada tahun 2014 STA Manik Mekar Nadi mendapat sertifikat prima-3 dari Pemerintah Provinsi Bali Dinas Pertanian Tanaman Pangan/Otoritas Kompeten Keamanan Pangan Daerah telah melaksanakan teknologi budidaya yang baik dan dinyatakan aman dikonsumsi komoditas cabai merah (capsicum annum L).

Melihat fenomena yang terjadi, dimana STA Manik Mekar Nadi merupakan STA terbaik di Bali dengan mendapat berbagai penghargaan di tingkat nasional maupun provinsi, serta dalam kegiatan usahanya menerapkan strategi pemasaran untuk memasarkan hasil produksi tanaman pertanian khususnya cabai merah. Hal ini mendorong penulis untuk melakukan penelitian mengenai strategi pemasaran cabai merah pada sub terminal agribisnis manik mekar nadi.

\subsection{Tujuan Penelitian}

Penelitian ini bertujuan untuk mengetahui faktor internal (kekuatan dan kelemahan) STA Manik Mekar Nadi, faktor eksternal (peluang dan ancaman) STA Manik Mekar Nadi, serta untuk mengetahui strategi yang tepat yang harus dilakukan oleh STA Manik Mekar Nadi dalam memasarkan cabai merah.

\section{Metode Penelitian}

\subsection{Lokasi dan Waktu Penelitian}

Penelitian ini dilakukan di STA Manik Mekar Nadi, Desa Besakih, Kecamatan Rendang, Kabupaten Karangasem, Provinsi Bali. Pemilihan lokasi penelitian dilakukan secara purposive, yaitu penentuan lokasi secara sengaja dengan dasar pertimbangan tertentu. Pengumpulan data dilakukan pada bulan April sampai dengan bulan Mei 2016.

\subsection{Penentuan Informan Kunci Penelitian}

Informan kunci adalah orang yang dimanfaatkan untuk memberikan informasi tentang situasi dan kondisi penelitian (Yudhantara, 2011). Pentuan informan kunci dilakukan dengan cara purposive yaitu tujuh orang yang dipilih secara sengaja dengan pertimbangan bahwa informan merupakan pengelola STA Manik Mekar Nadi yang mengerti mengenai proses pemasaran, serta beberapa informan kunci dari supermarket yang melakukan kerja sama dengan STA Manik Mekar Nadi yang dianggap memahami tentang kondisi STA tersebut sehingga mampu memberikan informasi sesuai dengan tujuan penelitian. Peneliti memilih ketua STA Manik Mekar Nadi, kepala cabang STA Manik Mekar Nadi, satu orang bagian pemasaran STA Manik Mekar Nadi, kepala gudang dan staff accounting dari supermarket Tiara Dewata, dan kepala gudang dan staff accounting dari supermarket Hardy's. 


\subsection{Metode Pengumpulan Data, Veriabel Penelitian, dan Analisis Data}

Metode pengumpulan data yang digunakan dalam penelitian ini adalah wawancara dan observasi lapangan. Variabel dapat diartikan sebagai segala sesuatu yang akan menjadi objek pengamatan penelitian yang memiliki nilai yang bervariasi (Antara, 2006). Variabel dalam penelitian ini adalah faktor lingkungan internal dan faktor lingkungan eksternal STA Manik Mekar Nadi yang diukur dengan skala ordinal. Analisis data yang digunakan dalam penelitian ini adalah IFAS, EFAS, analisis SWOT, dan analisis deskriptif kualitatif.

\section{Hasil dan Pembahasan}

\subsection{Karakteristik Informan Kunci}

Karakteristik informan kunci yang dijelaskan antara lain: 1) Umur, merupakan lamanya informan kunci hidup di dunia ini hingga dilakukannya penelitian ini. Kisaran umur keseluruhan informan kunci adalah 26 sampai 55 tahun, 2) Pendidikan, merupakan hal yang penting, karena jika diketahui tingkat pendidikan maka dapat diketahui pula kemampuan seseorang dalam menyerap pengetahuan. Data penelitian memperlihatkan bahwa sebanyak dua orang tamat SD, dua orang tamatan D2, dan tiga orang tamatan D3, 3) Pekerjaan/posisi, berdasarkan hasil penelitian dari tujuh informan kunci memiliki pekerjaan/posisi sebagai ketua STA Manik Mekar Nadi, kepala cabang STA Manik Mekar Nadi, bagian pemasaran STA Manik Mekar Nadi, kepala gudang dan staff accounting Tiara Dewata, kepala gudang dan staff accounting Hardy's.

\subsection{Faktor Internal}

Menurut Gitosudarmo (2008), faktor internal merupakan faktor penting yang berasal dari dalam tubuh suatu lembaga pemasaran yang terdiri dari kekuatan (strengths) dan kelemahan (weaknesses). Faktor internal strategi pemasaran cabai merah pada STA Manik Mekar Nadi dapat dilihat pada tabel 1.

Berdasarkan tabel 1, faktor kekuatan STA Manik Mekar Nadi, antara lain: 1) Lokasi STA yang strategis, diberi bobot 0,16 karena STA Manik Mekar Nadi merupakan lembaga pemasaran yang berada diwilayah produksi cabai merah, sedangkan diberi rating empat yang berpengaruh sangat kuat dalam menjalankan usahanya tersebut karena lokasi STA Manik Mekar Nadi sangat mudah dijangkau oleh petani. 2) Fasilitas yang dimiliki lengkap, diberi bobot 0,13 karena dengan fasilitas yang lengkap dapat bekerja dengan maksimal untuk memperoleh hasil yang diinginkan, sedangkan diberi rating tiga yang berpengaruh kuat terutama bagi ketahanan produk dan menambah nilai ekonomi produk cabai merah tersebut, 3) Memiliki pelanggan tetap, diberi bobot 0,16 karena STA Manik Mekar Nadi merupakan lembaga pemasaran yang sudah memiliki kerjasama dengan swalayan dan pasar tradisonal di Bali dengan demikian STA Manik Mekar Nadi sudah memiliki tujuan pasar yang jelas, sedangkan rating yang diberikan empat karena dengan memiliki pelanggan tetap dapat memberikan pengaruh yang sangat kuat 
untuk kemajuan dan kesejahteraan STA Manik Mekar Nadi dan petani cabai merah, dan 4) Kualitas cabai merah terjamin, diberi bobot 0,13 karena produk cabai merah yang dipasarkan oleh STA Manik Mekar Nadi merupakan produk yang aman dikonsumsi, sedangkan rating yang diberikan tiga yang berpengaruh kuat terhadap peningkatan volume penjualan.

Tabel 1.

Faktor Internal Strategi Pemasaran Cabai Merah pada STA Manik Mekar Nadi Tahun 2016

\begin{tabular}{lccc}
\hline \multicolumn{1}{c}{ Variabel } & Bobot & Rating & Skor \\
\hline Kekuatan: & & & \\
Lokasi STA yang strategis & 0,16 & 3,86 & 0,62 \\
Fasilitas yang dimiliki lengkap & 0,13 & 3,14 & 0,41 \\
Memiliki pelanggan tetap & 0,16 & 3,86 & 0,62 \\
Kualitas cabai merah terjamin & 0,13 & 3,29 & 0,43 \\
Kelemahan: & & & \\
Permodalan kurang mendukung & 0,13 & 3,14 & 0,41 \\
Produk tidak tahan lama & 0,10 & 2,57 & 0,26 \\
Belum mampu memenuhi permintaan & 0,09 & 2,14 & 0,19 \\
Belum menggunakan jasa/iklan dimedia massa & 0,10 & 2,71 & 0,27 \\
Total & 1,00 & & 3,21 \\
\hline Sumber: Dat Primer (digh), 2016.
\end{tabular}

Sumber: Data Primer (diolah), 2016.

Faktor kelemahan STA Manik Mekar Nadi, antara lain: 1) Permodalan kurang mendukung, diberi bobot 0,13 karena faktor ini memberikan dampak yang besar terhadap kelancaran dalam menjalankan sebuah usaha, sedangkan rating yang diberikan tiga yang berpengaruh kuat terhadap kelanjutan usaha dimasa yang akan datang dengan modal yang kurang maka kegiatan pemasaran akan sulit dilakukan, 2) Produk tidak tahan lama, diberi bobot 0,10 karena produk pertanian memiliki daya tahan produk yang rendah sehingga secara langsung akan lebih cepat rusak dan mempengaruhi dari kualitas produk itu sendiri, sedangkan rating yang diberikan tiga yang berpengaruh kuat dalam kegiatan penjualan dan pemasaran produk cabai merah tersebut, 3) Belum mampu memenuhi permintaan, diberi bobot 0,09 bobot yang diberikan sangat rendah dibandingkan faktor kelemahan yang lain, karena hal ini sangat jarang terjadi pada STA Manik Mekar Nadi dalam melakukan supply cabai merah, tetapi faktor ini juga akan menjadi kelemahannya dimasa depan. Rating yang diberikan dua pengaruh yang diberikan sangat sedikit, dan 4) Belum menggunakan jasa/iklan dimedia massa, diberi bobot 0,10 karena hal ini perlu di perhatikan oleh pengelola lembaga pemasaran STA Manik Mekar Nadi dalam melakukan promosi dimedia massa, sedangkan rating yang diberikan tiga dengan pengaruh yang kuat untuk kemajuan STA Manik Mekar Nadi. 


\subsection{Faktor Eksternal}

Faktor eksternal merupakan faktor yang berasal dari luar lingkungan perusahaan yang juga berpengaruh terhadap keberlangsungan atau jalannya suatu usaha dalam tubuh perusahaan (Rangkuti, 2015). Faktor eksternal strategi pemasaran cabai merah pada STA Manik Mekar Nadi dapat dilihat pada tabel 2.

Tabel 2.

Faktor Eksternal Strategi Pemasaran Cabai Merah pada STA Manik Mekar Nadi Tahun 2016

\begin{tabular}{lccc}
\hline \multicolumn{1}{c}{ Variabel } & Bobot & Rating & Skor \\
\hline Peluang: & & & \\
Permintaan pasar dalam negeri meningkat & 0,13 & 3,29 & 0,43 \\
Meningkatnya daya beli konsumen & 0,15 & 4,00 & 0,60 \\
Dukungan dari pemerintah & 0,16 & 4,00 & 0,60 \\
Perkembangan teknologi yang mendukung & 0,15 & 3,86 & 0,58 \\
Ancaman: & & & \\
Munculnya persaingan baru sejenis & 0,10 & 2,43 & 0,24 \\
Konsumen sensitif terhadap perubahan harga & 0,10 & 2,43 & 0,24 \\
Fluktuasi harga cabai merah dipetani lokal & 0,11 & 2,71 & 0,30 \\
Daya tawar konsumen semakin kuat & 0,10 & 2,57 & 0,26 \\
Total & 1,00 & & 3,25 \\
\hline Sum & & &
\end{tabular}

Sumber: Data Primer (diolah), 2016.

Berdasarkan tabel 2, faktor peluang STA Manik Mekar Nadi, antara lain: 1) Permintaan pasar dalam negeri meningkat, diberi bobot 0,13 karena STA. Manik Mekar Nadi memiliki kerjasama dengan beberapa pasar swalayan di Bali dan dengan meningkatnya permintaan pasar dalam negeri terhadap produk cabai merah akan memberi peluang pasar yang baik bagi STA Manik Mekar Nadi. Rating yang diberikan tiga karena memiliki peluang baik bagi STA Manik Mekar Nadi, 2) Meningkatnya daya beli konsumen, diberi bobot 0,15 karena daya beli konsumen sangat berpengaruh dalam menjalankan usaha, jika daya beli konsumen meningkat terhadap produk yang dipasarkan oleh STA Manik Mekar Nadi berarti konsumen masih percaya dengan kualitas produk yang dipasarkan dan hal ini akan membawa dampak untuk kemajuan STA Manik Mekar Nadi. Rating yang diberikan empat, karena memberikan peluang yang sangat besar dalam memasarkan produk cabai merah, 3) Dukungan dari pemerintah, diberi bobot 0,16 dengan pertimbangan bahwa lembaga pemasaran yang dijalankan oleh STA Manik Mekar Nadi sangat berpengaruh bagi kesejahteraan petani dan masyarakat Desa Besakih khususnya dan menunjang program Pemerintah. Rating yang diberikan empat, karena memberikan peluang yang sangat besar dalam menjalankan usahanya, dan 4) Perkembangan teknologi yang mendukung, diberi bobot 0,15 karena STA Manik Mekar Nadi dalam menajalankan usahanya tidak terlepas dari teknologi untuk mendukung kinerja karyawan, peranan teknologi sangat berpengaruh bagi kegiatan pemasaran dan STA 
Manik Mekar Nadi sampai saat ini mampu mengadopsi teknologi baru dalam hal operasional. Rating yang diberikan empat karena STA Manik Mekar Nadi sampai saat ini masih tergantung akan kebutuhan teknologi yang maju dan modern.

Faktor ancaman STA Manik Mekar Nadi, antara lain: 1) Munculnya persaingan baru sejenis, diberi bobot 0,10 karena hal ini bisa mengancam perkembangan STA Manik Mekar Nadi ke depannya apabila tidak disikapi dengan baik. Faktor ini diberi rating dua karena dapat mengancam STA Manik Mekar Nadi, 2) Konsumen sensitif terhadap perubahan harga, diberi bobot 0,10 karena perubahan harga yang terlalu sering dan harga yang tidak sesuai bisa menjadi ancaman bagi STA Manik Mekar Nadi karena menyangkut daya beli konsumen terhadap produk yang dipasarkan. Faktor ini diberi rating dua karena perubahan harga yang tidak sesuai dapat mengancam penurunan daya beli konsumen, 3) Fluktuasi harga cabai merah dipetani lokal, diberi bobot 0,11 karena fluktuasi harga cabai merah dipetani lokal menentukan harga jual yang ditetapkan oleh STA Manik Mekar Nadi ke pasar. Faktor ini diberi rating tiga karena dinilai kurang mengancam bagi STA Manik Mekar Nadi, sebab fluktuasi yang terjadi tidak terlalu signifikan dan dalam jangka waktu yang lama, dan 4) Daya tawar konsumen semakin kuat, diberi bobot 0,10 karena banyaknya usaha yang sejenis membuat daya tawar konsumen semakin kuat, hal ini perlu diperhatikan oleh STA Manik Mekar Nadi dalam menetukan kebijakan harga yang akan diberikan kepada pasar (konsumen). Faktor ini diberi rating tiga karena sejauh ini dinilai kurang mengancam bagi STA Manik Mekar Nadi.

\subsection{Strategi yang harus Dilakukan oleh STA Manik Mekar Nadi dalam Pemasaran Cabai Merah}

Strategi yang tepat untuk diterapkan STA Manik Mekar Nadi dalam memasarkan cabai merah yaitu dengan menggunakan strategi SO (strengths opportunities), WO (weaknesses opportunities), ST (strengths threats), dan WT (weaknesses threats). Strategi yang tepat diterapkan oleh STA Manik Mekar Nadi dapat dilihat pada tabel 3 . 


\section{Tabel 3.}

Matriks SWOT Strategi Pemasaran Cabai Merah pada STA Manik Mekar Nadi

Tahun 2016

\begin{tabular}{|c|c|c|}
\hline EFAS & $\begin{array}{l}\text { STRENGTHS (S) } \\
\text { a. Lokasi STA yang strategis } \\
\text { b. Fasilitas yang dimiliki } \\
\text { lengkap } \\
\text { c. Memiliki pelanggan tetap } \\
\text { d. Kualitas cabai merah } \\
\text { terjamin }\end{array}$ & $\begin{array}{l}\text { WEAKNESSES (W) } \\
\text { a. Permodalan kurang } \\
\text { mendukung } \\
\text { b. Produk tidak tahan lama } \\
\text { c. Belum mampu } \\
\text { memenuhi permintaan } \\
\text { d. Belum menggunakan } \\
\text { jasa/iklan dimedia massa }\end{array}$ \\
\hline 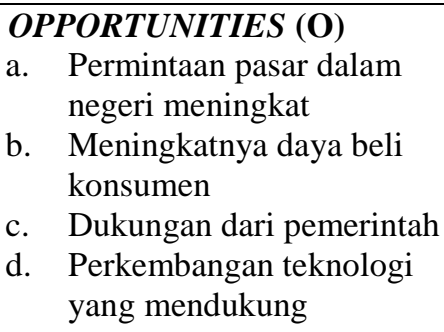 & $\begin{array}{l}\text { STRATEGI (SO) } \\
\text { a. Menjaga kualitas cabai } \\
\text { merah } \\
\text { b. } \\
\text { Memperluas jaringan } \\
\text { pemasaran dan distribusi } \\
\text { produk } \\
\text { c. } \\
\text { Meningkatkan produksi } \\
\text { cabai merah }\end{array}$ & $\begin{array}{l}\text { STRATEGI (WO) } \\
\text { a. Melakukan pinjaman } \\
\text { modal } \\
\text { b. Melakukan promosi } \\
\text { dengan teknologi yang } \\
\text { ada } \\
\text { c. Standarisasi produk }\end{array}$ \\
\hline 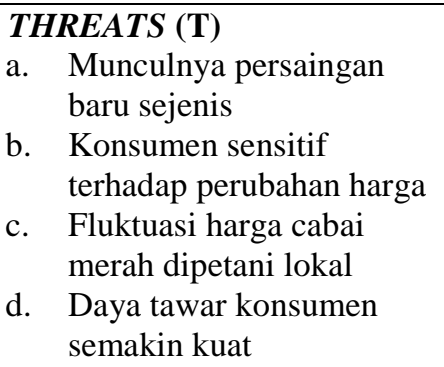 & $\begin{array}{l}\text { STRATEGI (ST) } \\
\text { a. Standarisasi harga } \\
\text { b. Memperluas jaringan usaha }\end{array}$ & 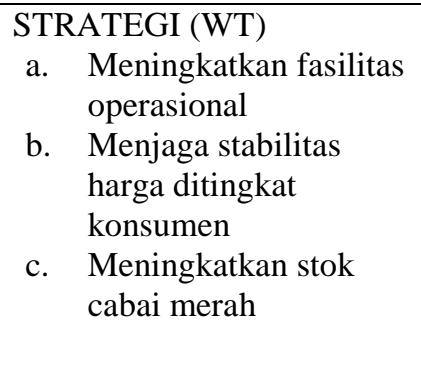 \\
\hline
\end{tabular}

Sumber: Data Primer (diolah), 2016.

Strategi yang diterapkan STA Manik Mekar Nadi dalam memasarkan cabai merah yaitu dengan menggunakan strategi SO yaitu, menjaga kualitas cabai merah, memperluas jaringan pemasaran dan distribusi, serta meningkatkan produksi cabai merah. Strategi WO yaitu, melakukan pinjaman modal, melakukan promosi dengan teknologi yang ada, dan standarisasi produk. Strategi ST yaitu, standarisasi harga dan memperluas jaringan usaha. Strategi WT yaitu, meningkatkan fasilitas operasional, menjaga stabilitas harga ditingkat konsumen, dan meningkatkan stok cabai merah, jika di bandingkan dengan strategi yang telah dikembangkan oleh CV Bali Aquarium adalah menentukan segmentasi, target, posisi, perbedaan, bauran pemasaran, penjualan, servis, proses (Suryawardani, 2007).

\section{Simpulan dan Saran}

\subsection{Simpulan}

Berdasarkan hasil dan pembahasan pada bab sebelumnya, dapat ditarik simpulan sebagai berikut.

1. Faktor internal STA Manik Mekar Nadi, meliputi: kekuatan (strengths) dari STA. Manik Mekar Nadi yaitu lokasi STA yang strategis, fasilitas yang dimiliki 
lengkap, memiliki pelanggan tetap, dan kualitas cabai merah terjamin sedangkan kelemahan (weaknesses) STA. Manik Mekar Nadi yaitu permodalan kurang mendukung, produk tidak tahan lama, belum mampu memenuhi permintaan, dan belum menggunakan jasa/iklan dimedia massa.

2. Faktor eksternal STA Manik Mekar Nadi, meliputi: peluang (opportunities) STA. Manik Mekar Nadi dalam memasarkan cabai merah yaitu permintaan pasar dalam negeri meningkat, meningkatnya daya beli konsumen, dukungan dari pemerintah, dan perkembangan teknologi yang mendukung, sedangkan ancaman (threats) yang harus dihadapi yaitu munculnya pesaing baru sejenis, konsumen sensitif terhadap perubahan harga, fluktuasi cabai merah dipetani lokal, dan daya tawar konsumen semakin kuat.

3. Strategi yang tepat diterapkan oleh STA. Manik Mekar Nadi dalam memasarkan cabai merah yaitu Strategi SO menjaga kualitas cabai merah, memperluas jaringan pemasaran dan distribusi produk, dan meningkatkan produksi cabai merah. Strategi WO melakukan pinjaman modal, melakukan promosi dengan teknologi yang ada, dan standarisasi produk. Strategi ST standarisasi harga dan memperluas jaringan usaha. Strategi WT meningkatkan fasilitas operasional, menjaga stabilitas harga ditingkat konsumen, dan meningkatkan stok cabai merah.

\subsection{Saran}

Berdasarkan hasil dan pembahasan pada bab sebelumnya, dapat disarankan sebagai berikut.

1. STA Manik Mekar Nadi mengalami keterbatasan modal, oleh karena itu sebaiknya STA ini mengajukan bantuan dana kepada Pemerintah atau mengajukan pinjaman kredit modal usaha dengan bunga rendah kepada bank.

2. Mengajukan bantuan kepada pemerintah untuk menambah alat transoprtasi yang menggunakan sistem pendingin dan memperluas gudang pendingin untuk penyimpanan cabai merah.

3. Memanfaatkan media sosial internet untuk melakukan promosi cabai merah, sehingga mampu menjangkau seluruh masyarakat.

\section{Ucapan Terima Kasih}

Penulis mengucapkan banyak terimakasih kepada semua pihak yang telah membantu dalam pelaksanaan penelitian ini, terutama kepada seluruh informan kunci sehingga penyusunan e-jurnal ini dapat selesai tepat pada waktunya.

\section{Daftar Pustaka}

Antara, M. 2006. Bahan Ajar Metodelogi Penelitian Agribisnis. Program Magister Agribisnis Program Sarjana Universitas Udayana, Denpasar.

Bali Mandara. 2016. Edisi 7. [Artikel Online]. Internet. http://issuu.com/tabloidbalimandara/doc/tmb_2016_eds_7_print. diunduh tanggal 15 September 2016. 
BPS. 2014. Jumlah Produksi Cabai Merah di Bali. [Artikel Online]. Internet. http://bali.bps.go.id/webbeta/website/brs_ind/brsInd-20150803132552.pdf. diunduh tanggal 27 Februari 2016.

Direktorat Pengolahan dan Pemasaran Hasil Holtikultura. 2004. Cabai Merah. [Artikel Online]. Internet. http://ditsayur.hortikultura.deptan.go.id. Diunduh 3 Maret 2016.

Gitosudarmo, Indriyo. 2008. Manajemen Strategis. Edisi Pertama. Yogyakarta: BPFE.

Rangkuti, Freddy. 2015. Personal SWOT Analisis. Jakarta: PT. Gramedia Pustaka Utama.

Satyanaraya. 2006. Berbagai Manfaat Cabai Bagi Kesehatan. [Artikel Online]. Internet. http://warintek.progressio.or.id/pertanian/cabe.htm. diunduh tanggal 3 Maret 2016.

Sinartani. 2014. Sub Terminal Agribisnis. [Artikel Online]. Internet. http://www.tabloidsanartani.com. Diunduh tanggal 8 Agustus 2016.

Suryawardani I.O., P.K. Patni, I.N.G. Ustriyana. 2007. Strategi Pemasaran Terumbu Karang CV Bali Aquarium. [e-jurnal]. Internet. Vol. 7. http://ojs.unud.ac.id/index.php/soca/article/view/4159

Yudhantara, K. 2011. Strategi Pemasaran Sayur Mayur pada PT. Adip Global Supplies Denpasar. Skripsi. Denpasar: Universitas Udayana Fakultas Pertanian 